\title{
13
}

\section{A Pivotal Moment for Global Nuclear Arms Control and Disarmament Policies: The Contribution of Robert O'Neill}

\section{Marianne Hanson}

\section{Introduction}

As a strategist and leading academic in the field of security studies, Robert $\mathrm{O}^{\prime}$ Neill was at the forefront of the re-imagining of the role of nuclear weapons, a re-imagining which has gathered strength since the 1990s, and which has shaped the current aspirations (if not yet the full practice) of leaders of the nuclear weapon states. Robert O'Neill's standing in the international strategic studies community and his willingness to reconsider prevailing assumptions about the utility of nuclear weapons have been instrumental in urging the nuclear weapons debate away a focus on Cold War deterrence thinking, and towards envisaging a nuclear weapon free world. Through his membership of the 1995-1996 Canberra Commission on the Elimination of Nuclear Weapons and the 1998 Tokyo Forum for Facing Nuclear Dangers, and his position on the Advisory Board of the 2008-2010 joint AustraliaJapan International Commission on Nuclear Non-proliferation and 
Disarmament, Robert $\mathrm{O}^{\prime} \mathrm{Neill}$ has played a key role in articulating how the changing nature of international security urgently requires us to re-think the role of nuclear weapons.

It is not an exaggeration to say that his scholarly research and commission activities have been highly influential in creating the climate where today, the leaders in almost every state have firmly declared their intention to seek a world without nuclear weapons. This aspiration is no longer something that is seen as naïve, radical, or strategically unwise (although there certainly are some die-hards who do retain a faith in nuclear weapons, and there is a long way to go before we reach a nuclear free world). The need to eliminate all nuclear weapons is a policy now firmly pursued even by hawks such as Henry Kissinger, ${ }^{1}$ numerous military leaders, ${ }^{2}$ various serving and former US national security advisers, secretaries of state and defense, and prominent world figures. ${ }^{3}$ It was a position made most evident by President Obama's clear call, in Prague in 2009, for a world without nuclear weapons, ${ }^{4}$ a most extraordinary statement made possible by the preceding years of debate and study on the role of nuclear weapons conducted by Robert O'Neill and others like him.

\section{Nuclear Weapons During the Cold War}

Like most strategists in the Cold War era concerned with the tension between the US and USSR and their allies, and the accompanying reliance on nuclear deterrence, Robert O'Neill's work focused very much on elements of arms control and nuclear postures. This is not to say, of course, that such strategists who saw value in nuclear deterrence were entirely happy about its logic or its potential dangers. Nuclear deterrence was never an entirely uncontroversial issue. But in a time of vertical proliferation of nuclear weapons - where at its height

\footnotetext{
1 Shultz, George P., William J. Perry, Henry A. Kissinger and Sam Nunn (2007) 'A World Free of Nuclear Weapons', Wall Street Journal, 2 January. Available at: www.wsj.com/articles/ SB116787515251566636.

2 Canadian Coalition for Nuclear Responsibility (1996) 'Statement by Generals and Admirals of the World Against Nuclear Weapons', 5 December. Available at: www.ccnr.org/generals.html. 3 As evidenced by the membership of Global Zero: www.globalzero.org/.

4 Obama, Barack (2009) 'Remarks by President Barack Obama in Prague', Whitehouse Press Release, April 5. Available at: www.whitehouse.gov/the-press-office/remarks-president-barackobama-prague-delivered.
} 
in the mid-1980s, the number of such weapons on the planet grew to around 70,000, with the vast majority of them being held by the US and the USSR ${ }^{5}$ - it was imperative to understand the dynamics of nuclear acquisition, deployment, and postures practised by those states which possessed nuclear weapons. These tens of thousands of weapons had a destructive power hundreds of times greater than the bombs used against Japan in 1945. And although the chief tension was that between the two superpowers, the addition of Britain (1952), France (1960) and China (1964) into the nuclear club during the Cold War added to the complexity of strategic thinking and calculation. In effect, one could not be a scholar of international security during the Cold War without considering the key role that nuclear weapons, or at least the threat of using nuclear weapons, played in that conflict.

These weapons were central to the security policies of the nuclear weapon states, which came to dominate strategic thinking and international affairs in a way that no other weapon has done. The Cold War became synonymous with the ever-present threat of catastrophic nuclear war, and planning to prevent it (and sometimes even to wage it - with nuclear war-fighting strategies, limited nuclear war, and even the idea of a winnable nuclear war all deliberated) occupied the minds of military thinkers and practitioners for decades. Their analyses and calculations ranged over notions such as deterrence, extended deterrence, flexible response, massive retaliation, counter-force and counter-value strategies, second-strike capabilities, and other elements that came with the onset of the atomic age, against a backdrop of the massive upward spiral in the numbers of nuclear weapons.

The core element was, of course, the idea of nuclear deterrence, the threat to use nuclear weapons against an adversary to dissuade that adversary from taking any undesired action, and especially to deter it from attacking one's own state or allies. ${ }^{6}$ Deterrence rested on a delicate psychological balance and, if it failed, would bring unparalleled disaster not only to the states concerned, but also to the wider world. As recognised by fellow Australian, Hedley Bull,

5 Bulletin of the Atomic Scientists (2015) Nuclear Notebooks: Nuclear Arsenals of the World. Available at: thebulletin.org/nuclear-notebook-multimedia.

6 Classic works on nuclear deterrence include Schelling, Thomas (1966) Arms and Influence, New Haven: Yale University Press; Schelling, Thomas and Morton Halperin (1961) Strategy and Arms Control, New York: The Twentieth Century Fund; and Freedman, Lawrence (2004) Deterrence, New York: Polity Press. 
with whom Robert $\mathrm{O}^{\prime}$ Neill was to work at the International Institute for Strategic Studies in London and The Australian National University, and whose insightful work on arms control Robert $\mathrm{O}^{\prime}$ Neill would masterfully survey and re-present in $1986,{ }^{7}$ the ${ }^{\prime}$ most important immediate goal of arms control' was to 'stabilise the relationship of mutual deterrence between the superpowers' ${ }^{8}$ Preventing nuclear war was the overwhelming objective, even if this meant exploring how to convince one's opponent that nuclear attack would be unleashed if one was duly provoked.

At its core, nuclear deterrence and its accompanying strategies relied on the promise of mutually assured destruction, or what came to be known as the MAD doctrine. Deterrence required, if it was going to be effective, clear communication between adversaries, a capacity to inflict the damage promised - that is, the actual nuclear weapon capability - and the credibility that such punishment would indeed be undertaken. The price to be paid for relying on deterrence was a robust stockpile, one which could withstand, if necessary, a first strike from one's adversary, and still be able to deliver a second strike in retaliation. This threat to use nuclear weapons (even in response to a nuclear attack) was always contentious, but for Bull, as $\mathrm{O}^{\prime}$ Neill notes, ${ }^{9}$ there was 'clearly a distinction between nuclear weapons intended for deterrence and nuclear weapons for use in combat'. The first category, Bull believed, had merit as an essential component of stability between the superpowers; in the absence of a durable peace between the US and the USSR, the pursuit of nuclear arsenals was a rational, if precarious, strategy. Deterrence also required that each state was to remain vulnerable to attack from the other if strategic stability was to be maintained; in this sense, and as Bull had noted, anti-missile defences were 'subversive of the real purpose of nuclear weapons', that purpose being to provide stable deterrence. ${ }^{10}$

$7 \quad$ O'Neill, Robert (ed.) (1986) Power and Policy: Doctrine, the Alliance, and Arms Control, London: Macmillan.

8 Bull, Hedley (1961) The Control of the Arms Race: Disarmament and Arms Control in the Missile Age, London: Weidenfeld \& Nicolson, p. 8.

9 O'Neill, Robert (ed.) (1986) Power and Policy: Doctrine, the Alliance, and Arms Control, London: Macmillan, p. 5.

10 Ibid. 
There remains no consensus among practitioners or scholars about the usefulness, workability, or moral standing of the policy of nuclear deterrence. Whether it was the determining factor that prevented war between the great powers, or whether it was ever truly reliable as a strategy, remain contentious questions. ${ }^{11}$ Nevertheless, any serious engagement with international relations during the Cold War could not avoid a focus on the complex and high-stakes issue of nuclear deterrence. As one of the most prominent and respected figures in strategic studies, Robert $\mathrm{O}^{\prime}$ Neill's notable contributions at the time to these questions included The Strategic Nuclear Balance: An Australian Perspective, ${ }^{12}$ the first comprehensive examination conducted in Australia of American, Soviet, and Chinese nuclear capabilities and policies, and their impact on nuclear arms control and non-proliferation; New Directions in Strategic Thinking, ${ }^{13}$ The Conduct of East-West Relations in the 1980s, ${ }^{14}$ Power and Policy: Doctrine, the Alliance and Arms Control; ${ }^{15}$ the aforementioned work, Hedley Bull on Arms Control, ${ }^{16}$ and numerous chapters and special lectures.

The 1970s and 1980s also saw the emergence of formal attempts to reduce the likelihood of nuclear war between the nuclear powers, and to prevent nuclear proliferation. The bilateral Strategic Arms Limitation Talks had resulted in the SALT Treaties of 1972 and 1979, both aimed at regulating the nuclear arms race between the US and the Soviet Union. For its part, the nuclear Non-Proliferation Treaty

11 Useful critiques of the role of nuclear weapons in the Cold War include those made by McGwire, Michael (1985) 'Deterrence: The Problem — Not the Solution', International Affairs 62(1), pp. 55-70; Lebow, Richard Ned and Janice Gross Stein (1995) 'Deterrence and the Cold War', Political Science Quarterly 110(2), pp. 157-81; and Price, Richard and Nina Tannenwald (1996) 'Norms and Deterrence: The Nuclear and Chemical Weapons Taboos', in Peter J. Katzenstein (ed.), The Culture of National Security: Norms and Identity in World Politics, New York: Columbia University Press. Some have even pointed to what has been called the essential 'irrelevance' of nuclear weapons as a determining factor in whether or not the superpowers went to war with each other. Mueller, John (1988) 'The Essential Irrelevance of Nuclear Weapons: Stability in the Postwar World', International Security 13(2), pp. 55-79.

12 O'Neill, Robert (ed.) (1975) The Strategic Nuclear Balance: An Australian Perspective, Canberra: Strategic and Defence Studies Centre, The Australian National University.

13 O'Neill, Robert and D. M. Horner (eds) (1981) New Directions in Strategic Thinking, London: Allen \& Unwin.

14 O'Neill, Robert (1985) The Conduct of East-West Relations in the 1980s, Hamden, Connecticut: Shoestring Press.

15 O'Neill, Robert (ed.) (1986) Power and Policy: Doctrine, the Alliance, and Arms Control, London: Macmillan.

16 O'Neill, Robert and David Schwartz (eds) (1987) Hedley Bull on Arms Control, London: Palgrave Macmillan. 
(NPT) of 1970 committed member states - other than the existing five nuclear powers, often referred to as the P5 because these are the same states which enjoy the right of permanent membership and veto power in the UN Security Council - to refrain from pursuing nuclear weapons. The Stockholm Conference in 1986 on Confidence and Security Building Measures, conducted by the OSCE (Organization for Security and Co-operation in Europe) was instrumental in forging processes of trust and verification between the Western and Eastern blocs, and led to the very important 1989 Conventional Forces in Europe (CFE) Treaty, bringing a long-overdue focus on the need to address conventional weapons and forces held by the opposing blocs. Between the Stockholm and CFE Treaties was the very important 1987 Intermediate-Range Nuclear Forces (INF) Treaty which agreed to eliminate completely the intermediate-range nuclear missiles held by the US and USSR.

While the CFE Treaty was clearly important as part of Gorbachev's focus on ending the Cold War, and the INF Treaty was a landmark agreement, ${ }^{17}$ the other treaties, at least in some ways, seemed to fall short of expectations. The SALT treaties did not bring about real reductions in the nuclear arsenals of the superpowers (although the successor Strategic Arms Reduction Talks (START) treaties which commenced in 1991 have done so). While it is true that the NPT has successfully limited the number of nuclear weapon states in the world (only four states - Israel, India, Pakistan and North Korea - have joined the nuclear ranks) it did nothing to curb the vertical proliferation of nuclear weapons, which reached a staggering peak of around 70,000 some 15 years after the NPT had been agreed. Nor has the NPT been able to bring the P5 nuclear weapon states to eliminate all of their weapons, something which they are obliged to do under Article VI of that treaty and by other legal decisions. It is this particular failure - the nuclear weapon states, despite their numerous pledges, are clearly not moving to zero (even though their

17 Unfortunately, even the successes of the CFE and the INF Treaties have stalled recently, as tensions between the US and Russia rise. These developments cannot be examined here, but useful summaries are provided by Collina, Tom Z. (2012) The Conventional Forces in Europe (CFE) Treaty and the Adapted CFE Treaty at a Glance, Arms Control Association Fact Sheet. Available at legacy.armscontrol.org/factsheet/cfe; Collina, Tom Z. (2014) ‘Russia Breaches INF Treaty, US Says', Arms Control Today, September. Available at: legacy.armscontrol.org/act/2014_09/News/ Russia-Breaches-INF-Treaty-US-Says. 
arsenals have shrunk considerably), and there are thousands of nuclear weapons, even 25 years after the end of the Cold War — which has produced a renewed focus on nuclear weapons for Robert $\mathrm{O}^{\prime} \mathrm{Neill}$.

\section{Rethinking the Role of Nuclear Weapons}

When the Cold War ended - unexpectedly, almost abruptly, but with much celebration - there arose the opportunity to take stock of the position in which the world now found itself, and to reconsider those assumptions and policies that had prevailed in international relations for the previous 40-odd years. This profound change in the structure of world politics allowed us the opportunity to reflect seriously on what kind of a world we now wished to live in, and what steps would be necessary to sustain and increase the peace brought by the ending of the superpower confrontation. In reality, however, this did not happen - at least not in any systematic or meaningful way. Many of the troubled issues that existed during the Cold War — such as the Israeli-Palestinian conflict, the simmering resentment against Western, and especially US, policies and presence in the Middle East more broadly, the grave inequalities between states and people of the world where extreme poverty and vulnerability existed for many and immense wealth and political influence prevailed for some - did not receive the attention they deserved, now that the threat of global annihilation seemed to have passed. This was especially true in two key and interrelated areas: Russia was more or less isolated after the Cold War, as NATO and the EU expanded eastwards at an unwise pace, and nuclear weapons continued to remain the central component of security policy for the nuclear weapon states, even though the very raison d'etre for these arsenals was now a thing of the past.

We had seen, however, the glimmer of an alternative nuclear future during the negotiations for the INF Treaty between Ronald Reagan and Mikhail Gorbachev in Reykjavik in 1986. There, both leaders had advanced the idea that it was not only possible, but indeed feasible and desirable, to seek full nuclear disarmament. Disagreements over various issues, especially Reagan's plans for missile defence, resulted in a more modest achievement - the elimination of intermediate range forces - but, as Nikolai Sokov notes, the meeting at Reykjavik had 'become a symbol of sorts - an example that nuclear disarmament 
is within reach as long as political leaders have courage to make such a decision and break through bureaucratic politics and the maze of arcane nuclear balance theories' ${ }^{18}$ Reykjavik came to represent a tantalising opening for the complete elimination of nuclear weapons, led by the two superpowers, ${ }^{19}$ but it was an opening that was not taken seriously or pursued at the time; nor was it revived by the nuclear weapon states, even when the Berlin Wall fell and the EastWest confrontation came to an end a few years later.

Nevertheless, the idea was kept alive by some: the Pugwash Conferences on Science and World Affairs produced a seminal work examining the desirability and feasibility of a nuclear free world, ${ }^{20}$ while the Henry L. Stimson Center, established in Washington DC in 1989, launched a substantial project on this same idea. The centre, as its website states, is geared toward 'providing policy alternatives, solving problems, and overcoming obstacles to a more peaceful and secure world'. In 1994, it began to examine the conditions under which the world might move toward the balanced and progressive elimination of nuclear weapons. Its Steering Committee brought out three reports. ${ }^{21}$ Among those on this Steering Committee were Robert McNamara, US Secretary of Defense from 1961-1968, and General Andrew Goodpaster, Supreme Allied Commander, Europe (SACEUR), from 1969-1974. The presence of such individuals from the policy and military fields was an important element in this new process.

\footnotetext{
18 Sokov, Nikolai (2007) 'Reykjavik Summit: The Legacy and a Lesson for the Future', Nuclear Threat Initiative. Available at: www.nti.org/analysis/articles/reykjavik-summit-legacy/.

19 For useful accounts of these negotiations, see Bunn, George and John B. Rhinelander (2007) Reykjavik Revisited: Toward a World Free of Nuclear Weapons, World Security Institute and Lawyers Alliance for World Security. Available at: cisac.fsi.stanford.edu/sites/default/files/BunnRhinelander-Reykjavik_Sept07.pdf; Goodby, James E. (2007) ‘Looking Back: The 1986 Reykjavik Summit', Arms Control Today, September. Available at: legacy.armscontrol.org/act/2006_09/ Lookingback.

20 Rotblat, Joseph et al. (1993) A Nuclear Weapon Free World: Desirable? Feasible? Oxford, Westview Press.

21 Stimson Center (1995) Beyond the Nuclear Peril: The Year in Review and the Years Ahead, Stimson Report 15, Steering Committee of the Project on Eliminating Weapons of Mass Destruction. Available at: www.stimson.org/images/uploads/research-pdfs/Report15.pdf; Stimson Center (1995) An Evolving US Nuclear Posture, Stimson Report 19, Steering Committee of the Project on Eliminating Weapons of Mass Destruction. Available at: www.stimson.org/ images/uploads/research-pdfs/Report 19.pdf; Stimson Center (1997) An American Legacy: Building a Nuclear Weapon Free World. Available at www.isn.ethz.ch/Digital-Library/Publications/ Detail/?ots591=0c54e3b3-1e9c-bele-2c24-a6a8c7060233\&lng=en\&id=93672.
} 


\section{The Canberra Commission Report}

In turn, it appears that these studies came to influence the thinking of Australian Prime Minister Paul Keating and his Minister of Foreign Affairs, Gareth Evans. Their creation of the Canberra Commission reflected a sense of optimism that nuclear elimination was possible. The NPT had been extended indefinitely in 1995, and Australia had helped to bring about a treaty to eliminate another kind of weapon of mass destruction, the Chemical Weapons Convention, in 1993. The Labor Government saw Australia as an activist middle-power, a 'good international citizen'. But the event that most led to the creation of the Canberra Commission was the resumption of French nuclear testing in the South Pacific. Keating noted:

No image in the twentieth century has seared our collective consciousness like that of the mushroom cloud. And in our minds that image of the bomb defined the Cold War ... We assumed that because the Cold War was over, the weapons that defined it had miraculously disappeared as well ... the realisation that this was not so came with the announcement by President Chirac, on 13 June 1995, that France would conduct a series of eight underground nuclear tests at Muroroa atoll in French Polynesia. ${ }^{22}$

Keating gathered a group of prominent, informed thinkers and practitioners into an independent commission and tasked them with assessing the options for a nuclear free world. He conceded that over the years, various anti-nuclear groups had campaigned for this, and had prepared many reports on nuclear dangers (and, indeed, civil society groups continue to be highly active in this field), but importantly, up until that time, no government had ever put its name to a report backing elimination. He stated:

I wanted to put the authority of a sovereign government behind the push to rid the world of nuclear weapons ... I thought we had an unprecedented and possible unrepeatable opportunity to begin to move to a new strategic environment which offered not just a reduction in the number of nuclear weapons, but their elimination. ${ }^{23}$

22 Keating, Paul (1998) 'Eliminating Nuclear Weapons: A Survival Guide for the Twenty-First Century', Public Lecture, University of New South Wales, 25 November. Available at: www. keating.org.au/shop/item/eliminating-nuclear-weapons---25-november-1998.

23 Ibid. 
Robert O'Neill, then Chichele Professor of the History of War at All Souls College, Oxford, was an obvious choice for membership of the Canberra Commission. Not only was he a gifted Australian scholar in international relations, holding prestigious positions at Oxford, the International Institute for Strategic Studies, and The Australian National University, but he was also an experienced soldier and strategist. He had first-hand knowledge of arms control, nuclear nonproliferation, nuclear strategy, and nuclear policy. In 2007, looking back on the Canberra Commission initiative, Robert $\mathrm{O}^{\prime}$ Neill was to state: 'it was clear to me that the role of nuclear weapons had changed since the end of the Cold War and it was high time to re-examine their utility. Proliferation had become a greater danger and the possibility of nuclear weapons falling into the hands of terrorists was another new factor to be addressed. ${ }^{24}$

Others among the 17 commissioners were former prime ministers, ambassadors, eminent scientists, and civilian and military leaders. Two of the commissioners had been part of the US military establishment: Robert McNamara, and General Lee Butler, former Commander in Chief of the US Strategic Air Command. Former Chief of the Defence Staff and head of British Armed Forces, Field Marshal Lord Carver, was an additional military voice. Their appointment was deliberate. The Keating Government recognised that the report would need to demonstrate its credibility to the security and defence policy communities if it was to be taken seriously.

Over the course of several months, the commissioners met to consider ways to reduce the dangers posed by the ongoing retention of nuclear weapons. It should be noted that at the outset, there was no clear consensus among the commissioners about the nature or extent of the problem, or about the steps which should be taken. But after several meetings, intense deliberation, and review of the technical and political issues canvassed by an extensive range of background papers, the commissioners' unanimous view presented in their report was that a balanced, phased, and verified elimination process was clearly necessary.

24 O'Neill, Robert (2007) 'World Order Under Stress: Issues and Initiatives for the TwentyFirst Century', Cunningham Lecture, The Academy of the Social Sciences in Australia. 
The report's essential message was as follows: as long as any one state has nuclear weapons, other states will want them also; as long as nuclear weapons exist, there is a chance that they will be used, either deliberately or by accident; and, that any use of nuclear weapons would be catastrophic. ${ }^{25}$ The report examined the strategic, technological, and political arguments usually put forward in support of retaining nuclear weapons, and made a comprehensive and persuasive case against them. It argued that without elimination, the world faced increased threats of proliferation, nuclear terrorism, and nuclear use.

As part of the growing debate on the issue of elimination, the report consolidated and extended the view that the utility of nuclear weapons - an issue that was never wholly or logically resolved, even during the Cold War - was even less convincing today. ${ }^{26}$ After all, despite their possession of vast nuclear arsenals, states have accepted stalemate or even defeat (the US in Vietnam, Soviet Union in Afghanistan, and France in Indo-China, when strategic and moral calculations ruled out any use of nuclear weapons in these conflicts) and have suffered calamitous assaults upon their territory (for instance, in September 2001 in the US, when the presence of a vast nuclear arsenal did nothing to deter terrorism and was utterly unhelpful in responding to it). Moreover, the new kinds of security threat faced by the world meant that nuclear weapons and nuclear deterrence were at best redundant, and at worst, obstacles to international security. ${ }^{27}$ The only utility accorded to nuclear weapons was that they possibly deterred against a nuclear attack by another nuclear state. But even in this case, the elimination of these weapons would be a positive gain. If nuclear weapons served no useful purpose, then retaining them would be costly, would invite further proliferation, and would sooner or later result in them being used.

\footnotetext{
25 Department of Foreign Affairs and Trade (1996) Report of the Canberra Commission on the Elimination of Nuclear Weapons, Canberra.

26 For detailed examinations of the commission's origin, arguments, and impact, see Hanson, Marianne and Carl J. Ungerer (1998) 'Promoting an Agenda for Nuclear Weapons Elimination: The Canberra Commission and Dilemmas of Disarmament', Australian Journal of Politics and History 44(4), pp. 533-51; Hanson, Marianne and Carl J. Ungerer (1999) 'The Canberra Commission: Paths Followed, Paths Ahead', Australian Journal of International Affairs 53(1), pp. 5-17.

27 Hanson, Marianne (2002) 'Nuclear Weapons as Obstacles to Security', International Relations 16(3), pp. 361-79.
} 
While urging that as strategic circumstances change, so too must strategic thinking, the Canberra Commission report laid out a series of practical immediate, reinforcing, and final steps which could be taken to move towards a nuclear weapon free world. Immediate steps - such as devaluing the role of nuclear weapons in security policies, taking nuclear forces off alert, removing warheads from delivery vehicles, hastening reductions between the US and Russia, negotiating a Comprehensive Test Ban Treaty and a Fissile Material Cut-Off Treaty, and providing mutual no-first-use pledges, were all things that the nuclear weapon states could do without damaging their security prospects. ${ }^{28}$

The commissioners agreed that while nuclear weapons could not be dis-invented, we could certainly devalue, phase-out, eliminate, and outlaw their possession and use. In the same way that prohibition regimes have been put in place for other weapons of mass destruction - chemical and biological weapons - prohibitions adhered to even by the most powerful states in the international system, so too could nuclear weapons be stigmatised and relegated to the annals of history. The fundamental thinking behind this concept, which has carried through to the present day, was that humans have the power to determine their future and to seek a world in which security can be achieved without recourse to inhumane weapons, which in any case are bound to have disastrous global impacts if they are ever used. We cannot dis-invent chemical or biological weapons, nor indeed the gas ovens used by the Nazis, but human sensibility and condemnation can produce legal constraints against what are increasingly seen to be inhumane, abhorrent, and unacceptable practices. Indeed it is this key idea which has led to the Humanitarian Initiative against nuclear weapons (discussed below). And in any case, as the commissioners pointed out, the sophisticated level of modern conventional weaponry is more than adequate to make it the first choice for military action: deterrence can be achieved with conventional weapons, as can any response to aggression and/or any instance of a state which seeks to develop nuclear weapons after a nuclear free world has been achieved. ${ }^{29}$

28 Department of Foreign Affairs and Trade (1996) Report of the Canberra Commission on the Elimination of Nuclear Weapons, Canberra.

29 For more detailed analysis of the utility of nuclear weapons and how this in turn shaped the commissioners' findings, see Hanson, Marianne (2002) 'Nuclear Weapons as Obstacles to Security', International Relations 16(3); Hanson, Marianne (2005) 'Regulating the Possession and Use of Nuclear Weapons: Ideas, Commissions, and Agency in International Security Politics: The Case of the Canberra Commission', in Ramesh Thakur, Andrew F. Cooper and John English (eds), International Commissions and the Power of Ideas, Tokyo: Nations University Press. 
The Australian Government had changed during the course of the Canberra Commission's deliberations, and Keating and Evans were no longer in power. The new conservative Liberal Government, which had sought to distance itself from its Labor predecessor, was lukewarm in its promotion of the report. Notwithstanding this, analysts from around the world recognised the value of the report as an independent analysis of the nuclear issue by distinguished and hard-headed experts. ${ }^{30}$

\section{The Tokyo Forum on Facing Nuclear Dangers}

The Canberra Commission had made the point that a world that was divided into states that had nuclear weapons and those that did not was unsustainable. In other words, while we had been successful in limiting the number of states that possessed nuclear weapons, we should not assume that this could be contained indefinitely. The five acknowledged nuclear weapon states under the NPT could not reserve to themselves the unique security benefits that nuclear weapons allegedly brought, while at the same time denying these same benefits to other states. The bargain of the NPT had been that non-nuclear states would promise never to acquire nuclear weapons, in exchange for the nuclear weapon states giving up their nuclear arsenals (albeit at some unnamed point). The nuclear states were to move to nuclear disarmament, and also assist non-nuclear weapon states wanting to utilise nuclear energy for peaceful purposes. The extension of the NPT in 1995 had been a reassertion of this bargain. Although some states were reluctant to extend the regime indefinitely — because extension clearly favoured the nuclear weapon states - they ultimately agreed to the extension, inter alia, on the basis that the nuclear armed states would fulfil their promise to disarm.

Yet this promise remains unfulfilled, even 25 years after the Cold War ended. Certainly the nuclear states have reduced their stockpiles considerably during this time — we now have 'only' around 16,000

30 Indicative was the assessment in the Bulletin of the Atomic Sciences which labelled the report as a 'no-nonsense road map'. Moore, Mike (1996) 'A Boost for Abolition', Bulletin of the Atomic Sciences 52(6). 
nuclear weapons in existence ${ }^{31}$ - but the pace of reductions has been slow. Moreover, most of the practical steps (suggested by the Canberra Commission and subsequent reports) have not been taken by the nuclear weapon states. Nuclear forces remain on high alert; all these states continue to modernise their nuclear arsenals, still touting the alleged benefits of their nuclear weapons in their security policies; the Comprehensive Nuclear-Test-Ban Treaty has not entered into force; and we have no Fissile Material Cut-off Treaty. The disillusion felt by many non-nuclear states has been palpable, and the vast majority of these have now given up hope that disarmament can be reached via the promises of the NPT.

India had long denounced the unequal nature of the NPT and a system that allowed the P5 to retain their arsenals while denying nuclear weapons to any other states. This sense of injustice, together with the rise to power of the hard-line Bharatiya Janata Party, led to India conducting nuclear tests in mid-May 1998, an event which propelled Pakistan to follow suit later that month. The proliferation of nuclear weapons to the South Asian continent (Israel had also developed a nuclear weapons capability, but refused to confirm or deny this) raised concerns throughout the world. It was denounced by most states, including by the nuclear weapon states, and prompted the then Prime Minister of Japan, Ryutaro Hashimoto, to establish a new commission, the Tokyo Forum for Nuclear Non-Proliferation and Disarmament, in August 1998. The forum met four times and produced its report in July 1999, Reducing Nuclear Dangers: An Action Plan for the Twenty-First Century. ${ }^{32}$

Once again, Robert $\mathrm{O}^{\prime}$ Neill was asked to contribute his experience and advice, although most members of the Tokyo Forum were newcomers to this kind of disarmament diplomacy and had not participated in the Canberra Commission. There were disagreements between some of the forum's members, but all subscribed to the general thrust of the report, namely, that the proliferation recently seen in South Asia was a harbinger of future dangers and that renewed attention had to be given to the issue of nuclear weapons. The forum differed from the

31 Arms Control Association (2015) Nuclear Weapons: Who has What at a Glance. Available at: www.armscontrol.org/factsheets/Nuclearweaponswhohaswhat.

32 Ministry of Foreign Affairs of Japan (1999) Facing Nuclear Dangers: An Action Plan for the Twenty-First Century: The Report of the Tokyo Forum for Nuclear Non-Proliferation and Disarmament. Available at: www.mofa.go.jp/policy/un/disarmament/forum/tokyo9907/. 
Canberra Commission in that it was a direct response to proliferation, and focused more on the dangers of proliferation, but essentially it reiterated what the Canberra Commission had painstakingly pointed out less than three years earlier. If the Canberra Commission appeared at a time of substantial optimism in world politics, the forum was a response to a deteriorated security landscape. The forum noted that 'much has changed since the Canberra Commission issued its important report in 1996', and that 'troubling signs are now evident on many fronts' ${ }^{33}$

Its first key recommendation was that the world must '[s]top and reverse the unravelling of the Nuclear Non-Proliferation Treaty regime by reaffirming the treaty's central bargain'. To do this, the nuclear weapon states were urged to demonstrate 'tangible progress in nuclear disarmament', and non-nuclear states pressed to work actively to discourage any further nuclear proliferation. The practical steps outlined in the Canberra Commission report were again urged, but there was an additional focus on stopping and reversing the proliferation in South Asia (Recommendation 11) and specific attention was paid to the dangers of missile proliferation and missile defence. In sum, this forum essentially amplified the Canberra Commission's message further; it too drew positive acclaim from various organisations and analysts.

Ultimately, however, and despite the best efforts of Canberra Commissioners and Tokyo Forum members, the nuclear weapon states paid little heed to their recommendations. Security conditions worsened in subsequent years, with the rise of jihadi-driven terrorism against the West and accompanying turmoil within the Middle East, the decision taken by North Korea in 2006 to join the ranks of the nuclear weapon states (and its four sets of nuclear tests, the most recent conducted on 6 January 2016), and an ongoing deterioration in US-Russian relations. Unfortunately, none of these developments help to persuade the leaders of the nuclear weapon states to take seriously the need for nuclear elimination, even though none of them could be addressed effectively by the use of nuclear weapons. The possession of an all-purpose nuclear security blanket - no matter how unsuitable such weapons are for preventing or responding to crises - continued to dictate the policies of these states. 
While modest reductions continued by the US and Russia (especially via the New START Treaty), none of the relatively cost-free practical steps have been taken, much to the dismay of most of the world's states. A number of other studies reiterated the points first made prominent by the Canberra Commission,,$^{34}$ and the important arguments in favour of elimination first made in 2007 by the highly authoritative American figures, George Shultz, William Perry, Henry Kissinger, and Sam Nunn, drew considerably on the groundbreaking work which $\mathrm{O}^{\prime}$ Neill and others had done earlier.

\section{A Renewed Emphasis on the Elimination of Nuclear Weapons: The Joint Australia- Japan International Commission on Nuclear Non-proliferation and Disarmament}

The election of a new Labor Government in Australia in 2007 saw a further attempt to address these issues. Former Foreign Minister Gareth Evans (who had overseen the Canberra Commission and served on the Blix Commission) was supported by new Prime Minister Kevin Rudd in reasserting Australian leadership in nuclear elimination by establishing the Joint Australia-Japan International Commission on Nuclear Non-proliferation and Disarmament (ICNND). Eminent individuals invited to the Commission's Advisory Board included Henry Kissinger, Sam Nunn, and George Shultz, as well as George Robertson (former British Secretary of Defence and Secretary-General of NATO). Again, Robert $\mathrm{O}^{\prime}$ Neill was enlisted to join this group, bringing with him his long years of scholarship in the field, and his positions on the Canberra Commission and Tokyo Forum. It is testament to O'Neill's esteemed standing that he has played such an important role right from the beginning of these endeavours, via the Canberra Commission, through to the most recent and extremely comprehensive

\footnotetext{
34 These included the Canadian Parliamentary Report, Canada and the Nuclear Challenge: Reducing the Political Value of Nuclear Weapons for the Twenty-First Century, which had appeared in December 1998, and the Weapons of Mass Destruction Commission Report: Weapons of Terror: Freeing the World of Nuclear, Biological and Chemical Arms (commonly known as the Blix Report) of July 2006.
} 
approach taken by the ICNND. Its report ${ }^{35}$ bears the hallmarks of the careful consideration given to these matters by Robert $\mathrm{O}^{\prime} \mathrm{Neill}$, and his contributions constitute a very important thread linking these works from 1995 through to the 2010 report, and beyond. His published work in this field after the Cold War, especially Alternative Nuclear Futures $^{36}$ and World Order Under Stress, ${ }^{37}$ add to his authoritative contributions to these crucial questions.

Clearly, these various reports have been instrumental in bringing about a re-thinking of the role of nuclear weapons in the post-Cold War era, and have resulted in the affirmation of the goal of a nuclear weapon free world by state leaders, military personnel, and notable others, including some unlikely sources. What we continue to see, however, is that even as the idea of zero nuclear weapons is becoming normalised, as leaders pledge their willingness to disarm, we are still a long way from the realisation of a nuclear free world. As a result, the 2015 Review Conference of the nuclear NPT saw a record number of states and organisations express their dismay and disappointment with the nuclear weapon states. $\mathrm{O}^{\prime} \mathrm{Neill}$ had pointed out in his Cunningham Lecture that 'the double standard built into the NPT is likely to prove fatal to the current regime'.$^{38}$ And so it appears to be the case. Many states have now lost hope that the NPT can bring about disarmament, as the P5 states seem unwilling even to adopt the practical steps long urged upon them. In response, 121 states have now signed the international pledge to ban nuclear weapons, an initiative that arose as the result of three important conferences held to examine the humanitarian consequences of nuclear weapons. This Humanitarian Initiative is likely to result in a nuclear weapon ban-treaty within a few years.

The nuclear weapon states will not support such a move. But this is an important development. While the nuclear states will not sign such a treaty, they are likely to be increasingly constrained by

35 International Commission on Nuclear Non-proliferation and Disarmament (2010) Eliminating Nuclear Threats: A Practical Agenda for Global Policymakers. Available at: icnnd.org/Pages/ default.aspx.

36 Baylis, John and Robert O'Neill (eds) (2000) Alternative Nuclear Futures: The Role of Nuclear Weapons in the Post-Cold War World, Oxford: Oxford University Press.

37 O'Neill, Robert (2007) 'World Order Under Stress: Issues and Initiatives for the Twenty-First Century', Cunningham Lecture, The Academy of the Social Sciences in Australia.

38 O'Neill, Robert (2007) 'World Order Under Stress: Issues and Initiatives for the Twenty-First Century', Cunningham Lecture, The Academy of the Social Sciences in Australia. 
a legal provision formally outlawing nuclear weapons. And while a ban-treaty will not, of course, lead automatically or immediately to elimination, it will assist in the process of further stigmatising and eventually outlawing the possession and use of nuclear weapons. In the past, the establishment of a legal prohibition has preceded the eventual elimination of a particular weapon (this has been the case with landmines, cluster munitions, biological and chemical weapons) and this is also likely to be a watershed development in the moves towards a nuclear free world.

Ultimately, of course, it is only the leaders of the nuclear weapon states who can take these steps, and commissioners and scholars can do no more than advocate for what they see as the most prudent course of action. But this does not mean that we should disregard the effects of these activities. They have been vital in raising public consciousness and keeping this issue alive, and in providing clear and achievable goals for the steady phasing-out of all nuclear arsenals. The activities of Robert O'Neill and others like him, and the works they have produced, remain an important body of knowledge which continues to inform current debates and decisions taken by advocacy groups, individuals and, increasingly, by states who are keen to see advances in disarmament.

\section{Conclusion}

One of the problems that has become evident over the years is that governments appear not to take seriously what expert security specialists have to say, even though these experts have decades of experience behind them, can point to the lessons of history, and are often able to take a detached and dispassionate view of issues. This was observed by Robert $\mathrm{O}^{\prime}$ Neill with reference to the invasion of Iraq in 2003. ${ }^{39} \mathrm{He}$ noted that there was widespread opposition to the Iraq War, and that he and the majority of his colleagues opposed that action on a number of grounds. Unfortunately, '[t]he US and allied governments simply put their fingers into their ears and took no notice of what experts had to say, while their soldiers and others ... have borne the fearful cost of this disregard'. He argues that there has

39 O'Neill, Robert (2007) 'World Order Under Stress: Issues and Initiatives for the Twenty-First Century', Cunningham Lecture, The Academy of the Social Sciences in Australia. 
been, 'a propensity of the leading Western governments participating, including our own [Australian Government] to ignore sound advice at the outset and then, when in trouble, to pretend that everything is going much better than it is'.

The same can be said of the nuclear elimination issue: nuclear states appear to believe that the nuclear status quo can be maintained indefinitely, and that the risks are low. In this sense, those who continue to rely on nuclear weapons to keep the peace, and who appear not to be worried by the prospect of accidental or terrorist use, are surely not realists, but might be better described as idealists. Such idealism is misplaced; we have been immensely fortunate that nuclear weapons have not been used since 1945. Hedley Bull made the point as early as 1961 that 'the danger of nuclear war by accident is more serious than that of deliberate and premeditated attack' ${ }^{40}$ This thought has also clearly influenced Robert $\mathrm{O}^{\prime}$ Neill. Numerous close calls have occurred, ${ }^{41}$ and it beggars belief to suggest that continuing with sanguine policies will save us from disaster. Robert Oppenheimer noted in 1946: 'It would seem to me visionary in the extreme, and not practical, to hope that methods which have so sadly failed in the past to avert war will succeed in the face of this far greater [nuclear] peril.' It is vital, as a fellow Canberra Commissioner, Richard Butler noted, to 'reverse history's greatest accident' by outlawing and eliminating nuclear weapons. ${ }^{42}$

But the reluctance to take the advice of experts who have closely studied these issues continues. Even the repeated calls for elimination made by Kissinger and his colleagues appear to have fallen on deaf ears. If these weapons - which might or might not have played a role in stabilising relations during the Cold War - are of little or no use today, and if their retention will lead to further proliferation, possible terrorist acquisition, and mistaken or deliberate use, and if today's security concerns require and can be met by a robust conventional capability - which

40 Bull, Hedley (1961) The Control of the Arms Race: Disarmament and Arms Control in the Missile Age, London: Weidenfeld \& Nicolson, p. 207.

41 Highly recommended are Schlosser, Eric (2013) Command and Control: Nuclear Weapons, the Damascus Accident, and the Illusion of Safety, New York: Penguin; and Lewis, Patricia et al. (2014) Too Close for Comfort: Cases of Near Nuclear Use and Options for Policy, London: Chatham House. Available at: www.chathamhouse.org/publications/papers/view/199200.

42 Butler, Richard (1996) The Elimination of Nuclear Weapons: Reversing History's Greatest Accident, The Sir Robert Madgwick Lecture, delivered at the University of New England, Armidale, 1 May. 
it is abundantly clear the great powers do possess - then there is no strategic need to maintain costly, imprecise, clumsy (in terms of military utility), dangerous and manifestly inhumane nuclear weapons.

Robert O'Neill and David Schwarz reminded us that Hedley Bull's contribution to the debate on arms control 'was based on a deep scepticism not only about those who urged rearmament, but also about those who advocated arms control and disarmament measures' ${ }^{43}$ It is quite clear that this approach has also informed Robert O'Neill's own work. For him, it has not been enough simply to accept prevailing practices, or to acquiesce to any fashion of the times and leave unexamined those things which deserve to be re-examined. By being willing to reconsider the role of nuclear weapons in a changed strategic landscape, he has given us a prudent assessment and a clear course to follow. He noted that Bull 'emphasized the need to re-examine the analytic assumptions underlying' various theories and practices, and it is clear that he has done the same thing when he reappraised the role of nuclear weapons. Reversing his previous thinking on the utility of these weapons required some courage, and a willingness to risk the ire of peers who continued to hold fast to the old doctrines.

There were many who were fortunate to study under the guidance of Robert O'Neill over the years, and who benefitted greatly from his intellectual energy and critical abilities. And we can continue to draw inspiration and strength from his post-academic activities. In 1981 he wrote that 'all who are professionally concerned with strategic thinking, particularly those who work in universities and the media' are obliged to 'make a major effort to stimulate wider discussion' of the security problems that beset the world.$^{44}$ Robert $\mathrm{O}^{\prime}$ Neill has done this most admirably in alerting the world to the nuclear dangers which continue to exist long after the Cold War has ended, and his efforts have paved the way for the acceptance, at least at a declaratory level, of the idea of eliminating nuclear weapons. We can seek to follow his example and hope that one day, his and our prescriptions for a safer world might be heeded.

43 O'Neill, Robert and David Schwartz (eds) (1987) Hedley Bull on Arms Control, London: Palgrave Macmillan.

44 O'Neill, Robert and D. M. Horner (eds) (1981) New Directions in Strategic Thinking, London: Allen \& Unwin. 
This text is taken from War, Strategy and History: Essays in Honour of Professor Robert O'Neill, edited by Daniel Marston and Tamara Leahy, published 2016 by ANU Press, The Australian National University,

Canberra, Australia. 